\title{
Oxygen and inorganic nitrogen contents and fluxes in burrows of the shrimps Callianassa japonica and Upogebia major
}

\author{
Isao Koike and Hiroshi Mukai
}

Ocean Research Institute, University of Tokyo, Nakano, Tokyo 164, Japan

\begin{abstract}
Concentrations of dissolved oxygen and inorganic nitrogenous compounds in burrows occupied by the shrimps Callianassa japonica (de Haan) and Upogebia major (de Haan) were compared to those in the overlying waters under simulated in situ conditions. Dissolved oxygen content in the burrow was considerably lower; it ranged from 12 to $45 \%$ of saturation values for $C$. japonica burrows and from 30 to $41 \%$ for $U$. major burrows respectively. One order of magnitude higher values for ammonium and 2 to 3 times higher nitrate plus nitrite values, compared to overlying waters, were also observed. Both oxygen and inorganic nitrogen data indicate that the burrow water is distinctively different from overlying waters and forms a unique microenvironment for benthic microorganisms. Estimated rates of irrigation by the burrowing shrimps, based on the oxygen balance in the burrow at $20.5^{\circ} \mathrm{C}$, were 32 to $89 \mathrm{ml} \mathrm{h}^{-1}$ for $\mathrm{C}$. japonica and 14 and $33 \mathrm{ml} \mathrm{h}^{-1}$ for U. major. Our data suggest that the burrow, formed and maintained by the burrowing shrimps, has roughly the same oxygen consumption and ammonium production as the surrounding sediment surface, the metabolically most active site in the sediment.
\end{abstract}

\section{INTRODUCTION}

The quantitative importance of benthic animals in the cycling of biogenic elements, such as carbon, nitrogen and phosphorus, in coastal and inshore ecosystems has been recognized rather recently (Rhoads, 1974; McCaffrey et al., 1980). In shallow waters, larger amounts of organic materials, produced in the euphotic layer, can reach the sediment surface than in the offshore environment and support the metabolism of benthic populations (Smith, 1978). In the sediment, benthic animals produce ammonium and phosphate directly as excreted metabolites and these essential nutrients recycle to the water column, sustaining primary production in the upper layers.

Among the benthic animals the burrow-dwelling macrofauna, such as burrowing thalassinids and polychaetes, are of particular importance in this respect. These burrowing animals can pump out their excreted material directly to the water column through their irrigation activities. The burrow, produced and maintained by the animals, forms a particular microenvironment for microbial populations; these decompose organic materials and recycle nutrients in the sediment (Aller and Yingst, 1978).

Physiological adaptations of burrowing animals, especially under low oxygen tension, have been studied in the laboratory (Farley and Case, 1968; Thompson and Pritchard, 1969; Felder, 1979). However, these studies were mainly concerned with the physiology and ecology of the animals, not with the flow of materials through the ecosystem. On the other hand, geochemical approaches have been applied to address the effect of benthic animals on nutrient recycling at the sediment-water interface (Grundmanis and Murray, 1977; Aller, 1978). The increased diffusion coefficients of inorganic nutrients in the upper portion of the sediment, due to reworking by benthic animals, was considered when a one-dimensional diffusion model was applied to estimate the fluxes of nutrients from the sediment (Vanderborght and Billen, 1975). Most of the previous discussions concerning bioturbation, however, is limited to either theoretical considerations or indirect evaluations, and thorough analyses of these processes are few (Dworschak, 1981; Gast and Harrison, 1981). Analyses of the burrow environment, 
as well as of the behavior and metabolism of the animals, are absolutely necessary for quantifying these processes.

In this paper we measured the concentrations of dissolved oxygen and inorganic nitrogen compounds in the burrows occupied by the burrowing thalassinids Callianassa japonica and Upogebia major under simulated field conditions, in order to characterize their burrow environment. The effects of burrowing activities on sediment metabolism are discussed, based on chemical analyses and metabolic of the animals' activities.

\section{MATERIALS AND METHODS}

Callianassa japonica (de Haan) and Upogebia major (de Haan) were collected in the intertidal zone of Yamada Bay $\left(39^{\circ} 28^{\prime} \mathrm{N}, 141^{\circ} 57^{\prime} \mathrm{E}\right)$, the estuary of the Orikasa River on the north Pacific coast of Japan. The limoria $(3 \mathrm{~cm}$ wide, 30 to $50 \mathrm{~cm}$ long and 30 to $50 \mathrm{~cm}$ high) were made with transparent acrylic-glass plates. The 'sea bottom' in the limoria was set up with intertidal sediment, and several cm of overlying water, running continuously. The wall of the limoria has small holes $(0.5 \mathrm{~cm}$ diameter $)$ fitted with rubber stoppers every $3 \mathrm{~cm}$ for collecting burrow water by hypodermic syringes, or to measure the oxygen content in the burrow by the outside electrode described below. Two or 3 shrimps were reared in each limorium. Burrow formation usually takes 1 or $2 \mathrm{~d}$. X-ray photographs showed that individual burrows had no connection to other burrows. We started the experiment after 4 to $5 \mathrm{~d}$ of pre-rearing.

\section{Measurements of oxygen and inorganic nitrogenous compounds in the burrow}

Dissolved oxygen concentrations in the burrows were measured by an oxygen electrode (Rank Brothers,

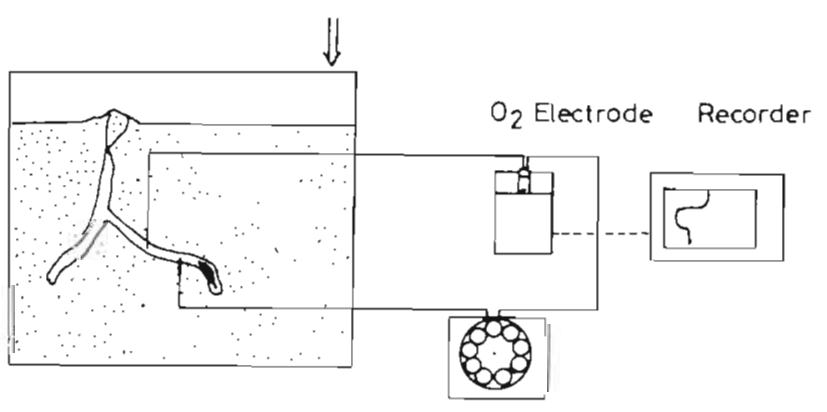

Peristaltic pump

Fig. 1. Limorium and oxygen electrode set-up used to measure dissolved oxygen concentration in the burrows of Callianassa japonica and Upogebia major
Cambridge, England) using the set-up shown in Fig. 1. The volume of the external system including the electrode cell was $3.5 \mathrm{ml}$, accounting for $\mathrm{ca} .10 \%$ of the average volume of the burrow (32 to $45 \mathrm{ml}$, Table 3 ). The temperature of the cell was adjusted to the water temperature of the limoria $\left(20.5^{\circ} \mathrm{C}\right.$ ). We selected a steady-state value of oxygen concentration in the burrow water obtained after 3 to 4 min circulation by a peristaltic pump at a speed of $4 \mathrm{ml} \mathrm{min}^{-1}$. The measurement was repeated several times at 20 to $30 \mathrm{~min}$ intervals. The oxygen electrode was calibrated by introducing oxygen-saturated seawater of known temperature and salinity into the electrode cell, both before and after measurement. After the oxygen measurement, ca. $7 \mathrm{ml}$ of burrow water was withdrawn from the sampling portion of the limoria with a hypodermic syringe. Nitrate plus nitrite and ammonium concentrations in the burrow water were measured by autoanalyzer methods of Strickland and Parsons (1972) and Head (1971), respectively, with slight modifications.

\section{Measurements of oxygen respiration by shrimp and oxygen consumption by sediment}

Shrimp oxygen respiration was measured by an oxygen electrode using the modified set-up (Fig. 1). The limorium in Fig. 1 was replaced by a small incubation vessel (ca. $22 \mathrm{ml}$ ). The shrimp (ca. 4 to $6 \mathrm{~cm}$ long) in the burrow was transferred to the vessel which contained oxygen-saturated, filtered seawater. The decrease in oxygen concentration in this system was continuously monitored, at a pump speed of $4.0 \mathrm{ml} \mathrm{min}^{-1}$, until the oxygen content was reduced to 60 to $70 \%$ of the saturation value. The observed oxygen decrease was almost linear with time during the measurement. Shrimp respiration rate was calculated from the slope of oxygen decrease and the volume of seawater in the system. Oxygen consumption by filtered seawater was negligible.

The sediments used for oxygen consumption measurements were collected with a Plexiglass tube $(3.6 \mathrm{~cm}$ diameter) from near the Callianassa japonica and Upogebia major burrows. The top $5 \mathrm{~cm}$ of the sediment was transferred to an incubation chamber ( $3.6 \mathrm{~cm}$ diameter). The water overlying the sediment was carefully replaced by filtered seawater and covered by a rubber stopper which has an inlet from and an outlet to the oxygen electrode cell. The volume of the overlying water was ca. $25 \mathrm{ml}$; oxygen consumption by the sediment was measured by circulating the overlying water through the oxygen electrode cell $\left(4 \mathrm{ml} \mathrm{min}^{-1}\right)$ the same way as described above. 


\section{RESULTS}

Average oxygen concentrations in the burrows of Callianassa japonica and Upogebia major are distinctively lower than in the oxygen-saturated overlying waters; they ranged from 12 to $45 \%$ saturation for $C$. japonica and from 30 to $39 \%$ for U. major (Table 1). During continuous flow of overlying waters, dissolved oxygen concentrations in the burrow showed no significant changes over 2 to $3 \mathrm{~h}$ of serial measurements (Fig. 2). Irrigation by the shrimp in the burrow keeps its immediate environment oxygenated; the oxygen concentration in the burrow depends both on the rate of irrigation and that of oxygen consumption by animals and microorganisms in the burrow. Fig. 2 suggests

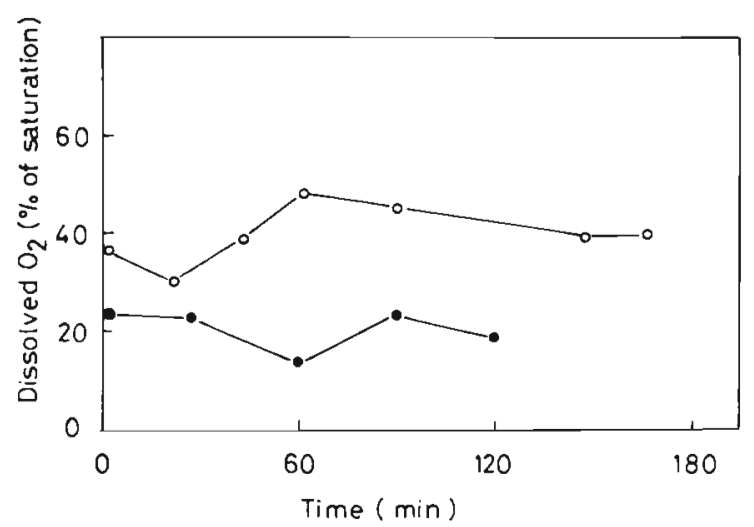

Fig. 2. Changes of dissolved oxygen concentrations in the burrows of Callianassa japonica ( ) and Upogebia major (O)

that, during a time span of 20 to $30 \mathrm{~min}$, both $C$. japonica and $U$. major continuously ventilate the burrow waters.

Because Callianassa japonica and Upogebia major have their habitats in the intertidal zone, their burrows are directly exposed to air during low tide. Low-tide condition was simulated by lowering the water level in the limoria to the sediment surface, and oxygen content in the burrow and behavior of $U$. major were monitored (Fig. 3). Within $1 \mathrm{~h}$ after draining the overlying waters, oxygen content in the burrow dropped from 54 to $16 \%$ saturation. After this rapid decrease, oxygen content in the burrow remained rather constant (13 to $18 \%$ ) for $5 \mathrm{~h}$ of simulated low tide. It recovered to $35 \%$ saturation within $40 \mathrm{~min}$ after return of overlying water. Corresponding to the decrease in dissolved oxygen content in the burrow, the shrimp spent much more time in the upper portion of the burrow and showed frequent irrigation motions. These motions probably increases the rate of atmospheric oxygen dissolution in the burrow water and support the respiration of $U$. major during low-tide. The shrimp stayed
Table 1. Dissolved oxygen concentrations in the burrows of Callianassa japonica and Upogebia major

\begin{tabular}{|ccc|}
\hline Species/Burrow & $\begin{array}{c}\text { Number of } \\
\text { measurements }\end{array}$ & $\begin{array}{c}\text { Dissolved oxygen } \\
\text { concentration }\end{array}$ \\
\hline & $(\mathrm{n})$ & $\begin{array}{c}(\overline{\mathrm{X}} \pm \mathrm{SD}, \\
\text { \% saturation })\end{array}$ \\
Callianassa japonica & & $21 \pm 4.2$ \\
Burrow 1 & 5 & $45 \pm 3.9$ \\
2 & 4 & $19 \pm 3.9$ \\
3 & 4 & $21 \pm 7.1$ \\
4 & 5 & $12 \pm 2.6$ \\
5 & 3 & $38 \pm 6.9$ \\
& & $30 \pm 5.7$ \\
Upogebia major & 6 & $41 \pm 11$ \\
Burrow 1 & 3 & $39 \pm 5.9$ \\
2 & 3 & \\
3 & 7 &
\end{tabular}

in the bottom portion of the burrow a long time after the overlying water had returned to the limorium.

Ammonium concentrations in burrow waters of both Callianassa japonica and Upogebia major were about 1 order of magnitude higher than those in overlying waters, ranging from 8.5 to $59.2 \mu \mathrm{g}$ at $\mathrm{N}^{-1}$ (Table 2). These increased ammonium concentrations in the burrow were again mainly the result of ammonium excretion by the shrimp and of ammonium production by microorganisms in the burrow. Nitrate plus nitrite concentrations in the burrow were also 2 or 3 times higher compared to those in overlying waters, suggesting nitrate or nitrite production in the burrow environment (Table 2). As is well known, nitrifying bacteria prefer a low oxygen concentration for growth (Goreau et al., 1980). Thus, the burrows of these benthic macrofauna representatives, characterized by low oxygen tensions

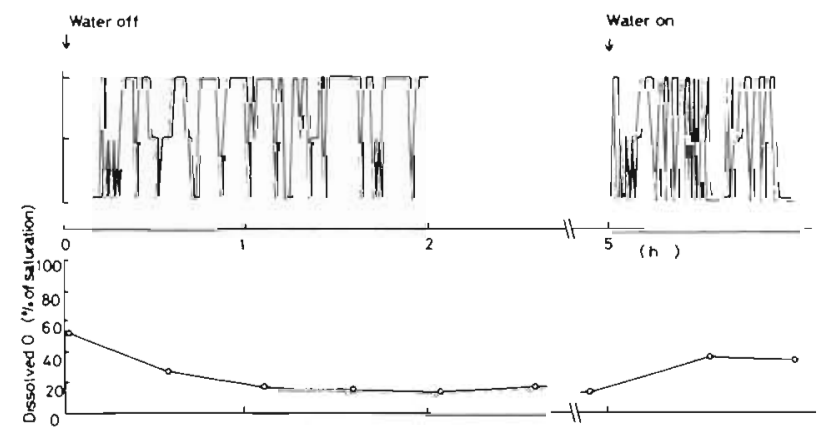

Fig. 3. Changes in dissolved oxygen concentration in the burrows of Upogebia major and behavior of the shrimp under simulated low-tide condition. The burrow was divided into 3 parts, i.e. upper, middle and bottom, and position and behavior of the shrimp were observed at 1-min intervals. Horizontal lines in upper panel indicate position of the shrimp. Top of upper panel is upper part and bottom of that is bottom part 
Table 2. Concentrations of inorganic nitrogenous compounds in the burrows of Callianassa japonica and Upogebia major and in the overlying water

\begin{tabular}{|ccccc|}
\hline Species/Burrow & Ammonium & $\begin{array}{c}\text { Nitrate } \\
\text { plus nitrite } \\
\left(\mu \mathrm{g} \text { at } \mathrm{N}^{-1}\right)\end{array}$ \\
\hline & $\mathrm{A}$ & $\mathrm{B}$ & $\mathrm{A}$ & $\mathrm{B}$ \\
$\begin{array}{c}\text { Callianassa japonica } \\
\text { Burrow 1 }\end{array}$ & 1.24 & 11.9 & 0.83 & 0.96 \\
2 & 3.44 & 59.2 & 0.96 & 2.06 \\
$\begin{array}{c}\text { Upogebia major } \\
\text { Burrow 1 }\end{array}$ & 1.12 & 8.50 & 1.83 & 3.78 \\
2 & 1.21 & 19.9 & 1.01 & 3.62 \\
A: overlying waters; B: burrow waters & & \\
\hline
\end{tabular}

(10 to $50 \%$ of saturation values; Table 1 ) and high ammonium concentrations, provide a suitable site for nitrification.

There was no large difference in respiration rates between Callianassa japonica and Upogebia major on the basis of dry weight. Observed respiration rates were 0.2 to $0.5 \mathrm{ml} \mathrm{O}_{2} \mathrm{~h}^{-1} \mathrm{~g}^{-1}$ at $20.5^{\circ} \mathrm{C}$ (Table 3).

Oxygen consumption by sediment collected from the intertidal zone of Yamada Bay at $20.5^{\circ} \mathrm{C}$ was $2.5 \pm 0.61 \mu \mathrm{l} \mathrm{O} \mathrm{h}^{-1} \mathrm{~cm}^{-2}(\overline{\mathrm{X}} \pm \mathrm{SD}, \mathrm{n}=5$, data not shown). Rates of oxygen consumption by surface sediment were in the range reported for shallow-water marine sediments (Bowman and Delfins, 1980).

\section{DISCUSSION}

The burrows occupied and maintained by Callianassa japonica and Upogebia major form a particular environment. Though the shrimp irrigate the habitat actively, the narrow outlet of the burrow com- pared to a large internal space severely restricts water exchange between burrow and overlying water (Mukai and Koike, unpubl.). Observed concentrations of dissolved oxygen and inorganic nitrogenous compounds in the burrow are significantly different from those of overlying waters (Tables 1 and 2).

If there was no exchange of burrow waters, the shrimp in the burrow would consume the dissolved oxygen completely within 30 to $60 \mathrm{~min}$. Serial measurements of dissolved oxygen in the burrow show no large variation, suggesting a balance between water exchange rate due to irrigation activity and oxygen consumption by benthic animals and microorganisms, except for the period of low tide.

Both burrowing crustaceans make their burrows with rigid walls (Mukai and Koike, unpubl.) and burrow-water exchange through the wall by irrigation is probably negligible, compared to that through the mouth of the burrow. Based on the oxygen balance in the burrow, we can estimate the average rate of irrigation $\left(\mathrm{v}, \mathrm{ml} \mathrm{h} \mathrm{h}^{-1}\right)$ and the turnover time of burrow water $(T, h)$ from the following equations:

$$
\begin{aligned}
& \mathrm{v}=\mathrm{dO}_{2} / \mathrm{dt} /\left(\mathrm{O}_{2} \text { out }-\mathrm{O}_{2} \text { in }\right) \\
& \mathrm{T}=\mathrm{V} / \mathrm{v}
\end{aligned}
$$

where $\mathrm{dO}_{2} / \mathrm{dt}=$ oxygen consumption rate in the burrow $\left(\mathrm{ml} \mathrm{O}_{2} \mathrm{~h}^{-1}\right) ; \mathrm{O}_{2}$ out and $\mathrm{O}_{2}$ in = oxygen contents outside and inside the burrow $\left(\mathrm{ml} \mathrm{O} \mathrm{O}_{2} \mathrm{l}^{-1}\right) ; \mathrm{V}=$ total volume of the burrow $(\mathrm{ml})$. We measured the average concentration of dissolved oxygen in the burrow by circulating the burrow water using a pump. For a first approximation, we used the rate of respiration by each shrimp in the burrow, measured under oxygen-saturated conditions, as the total oxygen consumption in the burrow. Microorganisms and chemical oxidants in the burrow wall also consume dissolved oxygen. Thus, the estimated irrigation rate is an underestimate. On the other hand, some decrease (30 to $50 \%$ ) in respira-

Table 3. Callianassa japonica and Upogebia major. Estimated irrigation rates and average turnover time of burrow waters (for

\begin{tabular}{|c|c|c|c|c|c|c|}
\hline Species & $\begin{array}{l}\text { Volume of } \\
\text { burrow } \\
\text { (ml) }\end{array}$ & $\begin{array}{c}\mathrm{O}_{2} \text { concentration } \\
\text { in burrow } \\
\left(\mathrm{ml} \mathrm{I}^{-1}\right)\end{array}$ & $\begin{array}{l}\mathrm{O}_{2} \text { respiration } \\
\text { by shrimp } \\
\left(\mathrm{ml} \mathrm{h}^{-1} \mathrm{~g}^{-1}\right)\end{array}$ & $\begin{array}{c}\text { Dry weight } \\
\text { of shrimp } \\
\text { (g) }\end{array}$ & $\begin{array}{l}\text { Irrigation } \\
\text { rate } \\
\left(m l h^{-1}\right)\end{array}$ & $\begin{array}{l}\text { Average turn- } \\
\text { over time of } \\
\text { burrow water } \\
\text { (min) }\end{array}$ \\
\hline \multicolumn{7}{|c|}{ Callianassa japonica } \\
\hline 1 & 45 & 1.69 & 0.52 & 0.27 & 39 & 69 \\
\hline 2 & 43 & 0.97 & 0.44 & 0.27 & 29 & 89 \\
\hline 3 & 32 & 2.20 & 0.48 & 0.21 & 37 & 52 \\
\hline 4 & 34 & 1.42 & 0.33 & 0.67 & 63 & 32 \\
\hline \multicolumn{7}{|c|}{ Upogebia major } \\
\hline 1 & 45 & 2.00 & 0.20 & 0.21 & 14 & 193 \\
\hline 2 & 45 & 1.89 & 0.28 & 0.39 & 33 & 82 \\
\hline
\end{tabular}
details see text) 
tion rate was observed in these benthic crustaceans when the dissolved oxygen content decreased to 10 to $30 \%$ saturation (Mukai and Koike, unpubl.), causing overestimation of irrigation rate. Estimated rates of irrigation at $20.5^{\circ} \mathrm{C}$ for Callianassa japonica ranged from 29 to $63 \mathrm{ml} \mathrm{h}^{-1}$, for Upogebia major from 14 to $33 \mathrm{ml} \mathrm{h}^{-1}$ (Table 3). Average turnover times of burrow waters ranged from 32 to $89 \mathrm{~min}$ for C. japonica and from 82 to $193 \mathrm{~min}$ for $U$. major. Reported irrigation rates for benthic invertebrates are 10 to $100 \mathrm{ml} \mathrm{h}^{-1}$ individual $^{-1}$ for various polychaetes and 100 to $1000 \mathrm{ml} \mathrm{h}^{-1}$ individual ${ }^{-1}$ for bivalves (Aller, 1977). Irrigation rates of $U$. pusilla and the alpheid shrimp Alpheus mackayi were recently reported as 5 to $900 \mathrm{ml}$ $\mathrm{h}^{-1}$ and $350 \mathrm{ml} \mathrm{h}^{-1}$, respectively (Dworschak, 1981; Gast and Harrison, 1981). Our observations indicate that $C$. japonica is a deposit feeder, and $U$. major a suspension feeder. Estimated irrigation rates of our shrimps were rather close to the range reported for polychaetes.

Burrowing and irrigation activities of the shrimp must exert significant influence on the decomposition of organic materials in sediments and on nutrient recycling from the sediment. Oxygen consumption by benthic organisms can be used as a relative index of the rates of organic-material decomposition in the sediment. The rate of oxygen consumption in the sediment near the burrows of the shrimps studied was 2.0 to $3.5 \mu \mathrm{l} \mathrm{O} \mathrm{h}^{-1} \mathrm{~cm}^{-2}$. This consumption rate is due mainly to the respiration of microorganisms and chemical oxidation. Callianassa japonica, a deposit feeder, also respires oxygen by decomposing organic materials from the sediment; the average observed respiration rate was $0.14 \mathrm{mI} \mathrm{h}^{-1}$ individual $^{-1}(0.10$ to 0.22$)$. The average surface area of a burrow occupied by $C$. japonica was estimated to be $120 \mathrm{~cm}^{2}$ (mean of 4 determinations) from $x$-ray photographs. Oxygen consumption of $C$. japonica normalized to the surface area of its burrow was calculated to be $1.2 \mu l \mathrm{O}_{2} \mathrm{~h}^{-1} \mathrm{~cm}^{-2}$. Judging from the uncertainty of acutal oxygen consumption rates in the burrow as discussed above, we conclude that the surface of the burrow wall consumes as much oxygen as does the sediment surface. Taking the standing stock of C. japonica to be 20 individuals $\mathrm{m}^{-2}$ (Mukai and Koike, unpubl.) in the intertidal zone of Yamada Bay, the burrowing activities of these shrimps enlarge the sediment surface area, which is metabolically the most active part of the sediment, by ca. $25 \%$.

Similar effects of burrowing crustaceans are also seen for recycling inorganic nitrogenous nutrients from the sediment. The burrow waters, which contain high amounts of nitrogenous nutrients, are continuously exchanged with overlying waters by irrigation. Estimated ammonium production - on the basis of irrigation rate and ammonium concentration in the burrow- ranged from 0.1 to $1.8 \mu \mathrm{g}$ at $\mathrm{N} \mathrm{h}^{-1}$ for a single burrow (average $0.94 \mu \mathrm{g}$ at $\mathrm{N} \mathrm{h}^{-1}$ ). Ammonium production by the intertidal sediment of Yamada Bay is on the order of $0.01 \mathrm{\mu g}$ at $\mathrm{N} \mathrm{h}^{-1} \mathrm{~cm}^{-2}$ (H. Iizumi, pers. comm.). Thus, the ammonium production of burrowed sediments (again we assume 20 individuals $\mathrm{m}^{-2}$ ) is ca. $20 \%$ greater than that of non-burrowed sediments. This value agrees well with the estimate for oxygen consumption.

The production of nitrate and nitrite in the burrow is primarily due to bacterial metabolism, while that of ammonium is the result of both benthic animals and microorganism metabolism. Assuming a steady-state condition in the burrow, the rate of nitrate plus nitrite production in the burrow is estimated to be $4.4 \times 10^{-4} \mu \mathrm{g}$ at $\mathrm{N} \mathrm{h}^{-1} \mathrm{~cm}^{-2}$ (average of 4 determinations). This is obviously an underestimate because of the simultaneous occurrence of nitrate reduction and denitrification in these sediments (Koike and Hattori, 1978).

In the intertidal zone of Yamada Bay there are many other species of macrofauna, including burrow-dwelling polychaetes and bivalves. Thus, the metabolism of these burrowing animals should be quantitatively very important for organic detritus decomposition and nutrient recycling in this ecosystem.

Acknowledgements. We are grateful to Professor Akihiko Hattori, Director of Otsuchi Marine Research Center, University of Tokyo, for supporting this work. Our study was supported in part by Grant 50325 from the Ministry of Education, Culture and Science, Japan.

\section{LITERATURE CITED}

Aller, R. C. (1977). The influence of macrobenthos on chemical diagenesis in marine sediments. Ph. D. Dissertation, Yale University, New Haven, Connecticut

Aller, R. C. (1978). Experimental studies of changes produced by deposit feeders on pore water, sediment, and overlying water chemistry. A.m. J. Sci. 278: 1185-1234

Aller, R. C., Yingst, J. Y. (1978). Biogeochemistry of the tubedwellings: a study of the sedentary polychaete Amphitrite ornata (Leidy). J. mar. Res. 36: 201-254

Bowman, G. T., Delfins, J. J. (1980). Sediment oxygen demand technique: a review and comparison of laboratory and in situ systems. Wat. Res. 14: 491-499

Dworschak, P. C. (1981). The pumping rates of the burrowing shrimp Upogebia pusilla (Petagna) (Decapoda: Thalassinidea). J. exp. mar. Biol. Ecol. 52: 25-35

Farley, R. D., Case, J. F. (1968). Perception of external oxygen by the burrowing shrimp, Callianassa californiensis DANA and C. affinis DANA. Biol. Bull. mar. biol. Lab., Woods Hole 134: 261-265

Felder, D. L. (1979). Respiratory adaptations of the estuarine mud shrimp, Callianassa jamaicense (Schmitt, 1935) (Crustacea, Decapoda, Thalassinidea). Biol. Bull. mar. biol. Lab., Woods Hole 157: 125-138

Gast, G., Harrison, J. T. (1981). Biological pumps at the 
sediment-water interface: mechanistic evaluation of the alpheid shrimp Alpheus mackayi and its irrigation pattern. Mar. Biol, 64: 71-78

Goreau, T. J., Kaplan, W. A., Wofsy, S. C., McElory, M. B. Valois, F. W., Watson, S. W. (1980). Production of $\mathrm{NO}_{2}^{-}$and $\mathrm{N}_{2} \mathrm{O}$ by nitrifying bacteria at reduced concentrations of oxygen. Appl. environ. Microbiol. 40: 526-532

Grundmanis, V., Murray, J. W. (1977). Nitrification and denitrification in marine sediments from Puget Sound. Limnol. Oceangr. 22: 804-813

Head, P. C. (1971). An automated phenolhypochlorite method for the determination of ammonia in sea water. Deep Sea Res. 18: 531-532

Koike, I., Hattori, A. (1978). Simultaneous determination of nitrification and nitrate reduction in coastal sediments by a ${ }^{15} \mathrm{~N}$ dilution technique. Appl. environ. Microbiol. 35: 853-859

McCaffrey, R. J., Myers, A. C., Davery, E., Morrison, G., Bender, M., Luedtke, N., Cullen, D., Froelich, Ph., Klink- hammer, G. (1980). The relationship between pore water chemistry and benthic fluxes of nutrients and manganese in Narragansett Bay, R. I. Limnol. Oceanogr. 25: 31-44

Rhoads, D. S. (1974). Organism-sediment relations on the muddy sea floor. Oceanogr. mar. Biol. A. Rev. 12: 263-300

Smith, K. L. (1978). Benthic community respiration in the N. W. Atlantic Ocean. A in situ measurement from 40 to 5200 m. Mar. Biol. 47: 337-347

Strickland, J. D. H., Parsons, T. R. (1972). Practical handbook of sea water analysis. Bull. Fish. Res. Bd Can. 167: 1-470

Thompson, R. K., Pritchard, A. W. (1969). Respiratory adaptations of two burrowing crustaceans, Callianassa californiensis and Upogebia pugettensis (Decapoda, thalassinidea). Biol. Bull. mar, biol. Lab., Woods Hole 136: $274-287$

Vanderborght, J. P., Billen, G. (1975). Vertical distribution of nitrate concentration in interstitial water of marine sediments with nitrification and denitrification. Limnol. Oceanogr. 10: 953-961

This paper was submitted to the editor; it was accepted for printing on March 18, 1983 